\title{
Insecticidal activity of 2-tridecanone against the cowpea weevil Callosobruchus maculatus (Coleoptera: Bruchidae)
}

\author{
YUSSEF F.B. BRAGA ${ }^{1}$, THALLES B. GRANGEIRO ${ }^{1}$, EDER A. FREIRE ${ }^{1}$, \\ HELANO L. LOPES ${ }^{2}$, JOSÉ N.S. BEZERRA ${ }^{2}$, MANOEL ANDRADE-NETO ${ }^{2}$ \\ and MARY ANNE S. LIMA ${ }^{2}$ \\ ${ }^{1}$ Laboratório de Genética Molecular, Departamento de Biologia, Universidade Federal do Ceará \\ Caixa Postal 12.200, 60971-270 Fortaleza, CE, Brasil \\ ${ }^{2}$ Departamento de Química Orgânica e Inorgânica, Universidade Federal do Ceará \\ Caixa Postal 12.200, 60971-270 Fortaleza, CE, Brasil \\ Manuscript received on October 10, 2005; accepted for publication on July 19, 2006; \\ presented by RAYMUNDO BRAZ-FILHO
}

\begin{abstract}
The effect of 2-tridecanone vapor on the cowpea weevil (Callosobruchus maculatus) development was determined. Seeds of cowpea were infested with adults and exposed to different doses of 2-tridecanone isolated from Pilocarpus microphyllus Stapf ex Holm, a plant species native from northeastern Brazil. The pure monoterpene was evaluated both undiluted as well as in the dilutions 1:10, 1:100 and 1:1,000 (v/v). The following parameters of the cowpea weevil life cycle were analyzed in response to decreasing doses of 2-tridecanone: number of eggs laid, percentage of egg hatching on seeds, percentage of adult emergence, adult weight at emergence, mean developmental time and number of adults emerged. Vapor of 2-tridecanone caused a significant $(\mathrm{P}<0.05)$ reduction in the number of eggs laid, in the percentage of eggs hatched and in the number of emerged adults in infested seeds. The fumigant insecticidal effect of 2-tridecanone was mainly due to its ovicidal activity.
\end{abstract}

Key words: Callosobruchus maculatus, cowpea, 2-tridecanone, Pilocarpus microphyllus.

\section{INTRODUCTION}

Cowpea [Vigna unguiculata (L.) Walp.] is one of the most widely adapted, versatile, and nutritious grain legumes (Ehlers and Halla 1997). It has been consumed by humans since the earliest practice of agriculture in developing countries of Africa, Asia and Latin America, where it is especially valuable as a source of dietary proteins as well as vitamins and minerals (Singh et al. 2003) Substantial quantities of cowpea are produced in semiarid northeastern Brazil, however before harvest or during storage the seeds are vulnerable to infestation by many insect pests, constituting the major constraint on the food availability. In this region, over $90 \%$ of the

Correspondence to: Manoel Andrade-Neto

E-mail: mannt@dqoi.ufc.br insect damage to cowpea seeds is caused by the "cowpea weevil" Callosobruchus maculatus F. (Coeloptera: Bruchidae), a pest of several pulses including chickpeas (Cicer arietinum L.), lentils (Lens culinars Medik.), soybeans (Glycine max Mer.) and common beans (Phaseolus vulgaris L.). Indeed C. maculatus infestation on stored legumes may reach $50 \%$ within 3-4 months of storage (Pascual-Villalobos and Ballesta-Acosta 2003).

It has been well reported that terpenes from a variety of essential oils have potent insect pest-control properties, and they have being found to affect the biology of target insects in different modes such as ovicides, repellents, antifeedants, fumigants and contact toxicants, and insecticides (Watanabe et al. 1993, Hough-Goldstein 1990, Karr and Coats 1988, Rice and Coats 1994, Tsao 
et al. 1995). The effectiveness of many essential oils as fumigants and contact insecticides in protecting cowpea seeds against $C$. maculatus infestation has been studied, and this beetle has shown susceptibility to some plantderived chemicals (Shaaya et al. 1997, Keita et al. 2000, 2001, Raja et al. 2001).

With the goal to identify plant-produced substances active against economically important insect pests, we report in the present work the fumigant activity of the 2tridecanone, the major constituent of the seed essential oil from Pilocarpus microphyllus, against the cowpea weevil C. maculatus.

\section{MATERIALS AND METHODS}

\section{Plant Material}

Pilocarpus microphyllus Stapf ex Holm was collected in Barra do Corda, Maranhão, Northeast of Brazil. A voucher specimen (n. 24.848) has been identified by Dr. Manoel Andrade Neto and deposited at the Herbário Prisco Bezerra (EAC), Departamento de Biologia, Universidade Federal do Ceará, Fortaleza, Ceará, Brazil.

\section{INSECTS}

A laboratory culture of Callosobruchus maculatus (F.) was established in July of 1996 from infested seeds obtained from local markets in Fortaleza. The stock culture of $C$. maculatus was maintained on susceptible commercial seeds (variety EPACE-10) purchased at local stores. All rearing and experiments were carried out in an incubator at a constant temperature of $27^{\circ} \mathrm{C} \pm 2^{\circ} \mathrm{C}, 60-70 \%$ relative humidity and with a photoperiod of $12 \mathrm{~h}$ light and $12 \mathrm{~h}$ dark.

\section{Extraction of the Volatile Constituents}

$53.0 \mathrm{~g}$ of the seeds from Pilocarpus microphyllus were submitted to hydrodistillation for 3 hours in a Clevengertype apparatus. The essential oil was dried over anhydrous sodium sulfate to yield a clear yellow oil in $0.15 \%$ yield.

\section{Analysis of the Volatile Constituents}

Analysis of the volatile constituents of the essential oil was performed by CG/MS on a Hewlett-Packard 5971 GC/MS instrument equipped with a dimethylpolysiloxane DB-5 fused silica capillary column $(30 \mathrm{~m} \times 0.25 \mathrm{~mm}$;
$0.25 \mu \mathrm{m}$ film thickness) and Helium as carrier gas at a flow-rate of $1 \mathrm{~mL} / \mathrm{min}$ and the temperature programmed from $35^{\circ} \mathrm{C}-180^{\circ} \mathrm{C}$ at a $4^{\circ} \mathrm{C} / \mathrm{min}$ rate and $180^{\circ} \mathrm{C}-280^{\circ} \mathrm{C}$ at a $20^{\circ} \mathrm{C} / \mathrm{min}$ rate. The injector and detector were maintained at $250^{\circ} \mathrm{C}$ and $200^{\circ} \mathrm{C}$, respectively. The mass spectra were taken over the $m / z, 28-400$ range with an ionizing voltage of $70 \mathrm{eV}$. Identification of individual components of the essential oil was performed by computer library MS search based on their Kovat's retention indices as a preselection routine (Craveiro et al. 1984, Alencar et al. 1990), and comparison of the fragmentation pattern with published spectral data (Adams 2001, Stenhagen et al. 1974). Analysis by GC/MS revealed the 2-tridecanone as the only constituent of the essential oil (100\%) (Figure 1). Its structural characterization was accomplished by mass spectral analysis and NMR experiments, uni and bidimensional, run on a Bruker DRX 500 spectrometer, and posterior comparison with published data.

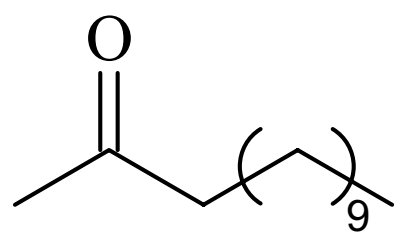

Fig. 1 -2-Tridecanone.

\section{INSECTICIDAL BIOASSAYS}

To investigate the fumigant effects of 2-tridecanone on C. maculatus development, the pure compound was evaluated both without any dilution as well as diluted (1:10, $1: 100$, and 1:1,000, v/v) in 100\% ethanol. All bioassays were carried out in small plastic containers $(3 \mathrm{~cm}$ diameter $\times 4.7 \mathrm{~cm}$ height $)$ and the sample to be tested $(100 \mu \mathrm{L})$ was applied on a small filter paper disk $(2 \mathrm{~cm}$ diameter) which was then laid on the inner downside of the container. Each filter paper disk was then covered with a disk of cheese cloth with the same diameter so as to avoid direct contact of the sample with the insects. Thereafter, for each treatment as well for the control (seeds exposed to $100 \%$ ethanol), 200 seeds (three replicates) were introduced in each treated container and provided as oviposition sites for five males and five females of $C$. maculatus (aged 0-24 h). 
After the oviposition period had finished (about one week) the total number of eggs laid (hatched and unhatched) was recorded, and seeds were observed for 50 days for adult emergence. Moreover, the disks of filter paper where the tested samples were applied were maintained inside the containers until the last day of the experiment. The date when each adult emerged and its weight were then recorded. The developmental period (time of egg laying to adult emergence) and the percentage of adult emergence (number of adults emerged $\times 100$ /number of hatched eggs) were calculated. All data obtained were subjected to analysis of variance (ANOVA) and means were compared using Tukey's test.

\section{RESULTS AND DISCUSSION}

The resistance of wild tomato species, Lycopersicon hirsutum Humb \& Bonpl. and L. hirsutum f. glabratum c.h. Mull, to many arthropod pests including the tobacco hornworm, Manduca sexta (L.) (Williams et al. 1980), the tomato fruitworm Heliothis zea (Boddie) (Williams et al. 1980), the Colorado potato beetle, Leptinotarsa decemlineata (Say.) (Kennedy et al. 1991), and the tomato pinworm, Tuta absoluta (Meyrick) (Gilardon et al. 2001) was conditioned by large amounts of the 2-tridecanone (Fig. 1) in the type VI glandular trichomes. The insecticidal activity against the insect herbivores Keiferia lycopersicella and Spodoptera exigua was also reported (Lin et al. 1987).

2-tridecanone is the major constituent of the essential oils from Pilocarpus species (Rutaceae) native from northeastern Brazil: P. jaborandi, P. trachyllophus, P. grandiflorus and P. spicatus (Andrade-Neto et al. 1995, 2002, Craveiro et al. 1979). In this work, the vapor of the pure 2-tridecanone isolated from Pilocarpus microphyllus proved to be toxic against the cowpea weevil, Callosobruchus maculatus. Six biological parameters of C. maculatus development were analyzed and vapor of 2-tridecanone significantly $(\mathrm{P}<0.05)$ affected the total number of eggs laid on seeds, the percentage of egg hatching, the total number of emerged adults and the percentage of adult emergence (Table I). The fumigant toxic effects of 2-tridecanone resulted in lower oviposition, higher egg mortality and decreased numbers of emerged adults from treated seeds. For all these affected biological parameters of $C$. maculatus by 2 -tridecanone vapor, the intensity of the effects was directly proportional to the concentration of the applied doses (Table I).

A significant $(\mathrm{P}<0.05)$ reduction (ca. 48.2\%) in the mean number of eggs laid was observed when adult females were exposed to undiluted 2-tridecanone. In contrast the highest dilution of 2-tridecanone $(1: 1,000)$ produced an increase in the mean number of eggs laid, although this was not significantly higher $(\mathrm{P}>0.05)$ than the average oviposition rate observed in the control. Furthermore, the percentage of hatched eggs was significantly $(\mathrm{P}<0.05)$ reduced in the presence of either undiluted 2-tridecanone (89\%) or 2-tridecanone 1:10 $(51 \%)$. In addition, the percentage of adult emergence in the treatment with undiluted 2-tridecanone was significantly $(\mathrm{P}<0.05)$ lower $(66 \%)$ in relation to the control $(91 \%)$. On the other hand, the vapor of 2-tridecanone did not show any significant $(\mathrm{P}>0.05)$ effect on the mean developmental time and the average weight of freshly emerged adults of $C$. maculatus (Table I).

The exposure of the cowpea seeds to the vapor of 2-tridecanone was very effective to control their infestation by $C$. maculatus since the total number of adults emerged was significantly $(\mathrm{P}<0.05)$ reduced $(96 \%)$ when compared to untreated seeds. The results show that 2-tridecanone exhibit fumigant toxicity and its efficacy in protecting the cowpea seeds against $C$. maculatus is mainly due to its ovicidal activity. Since the percentage of adult emergence is based on the proportion of hatched eggs that develop into adults inside the seeds, the results also suggest that 2-tridecanone vapor can cross the seed coat and therefore interfere with the larvae development. To our best knowledge this is the first report on the insecticidal activity of 2-tridecanone against the cowpea weevil.

Cowpea is now one of the world's important legume food crops with an estimated cultivated area of about 14 million ha and an annual production of over 4.5 million metric tons (Mt) worldwide. A substantial part of cowpea production comes from Nigeria (about 5 million ha, with $2.1 \mathrm{Mt}$ ), Niger (about 3 million ha, with $0.6 \mathrm{Mt}$ ) and Brazil (about 1.9 million ha, with $0.7 \mathrm{Mt}$ ) (Singh et al. 2003). Production of cowpea in Brazil is concentrated in the northeast, an under-developed, semiarid region where the intensive use of industrialized pesticides by most farmers is impracticable. In this con- 
TABLE I

Effects of 2-tridecanone on the cowpea weevil Callosobruchus maculatusa ${ }^{a}$

\begin{tabular}{l|c|c|c|c|c|c}
\hline \multicolumn{1}{c|}{ Treatment } & $\begin{array}{c}\text { Number } \\
\text { of eggs } \\
\text { laid }\end{array}$ & $\begin{array}{c}\text { Percentage } \\
\text { egg hatch } \\
\text { on seeds }\end{array}$ & $\begin{array}{c}\text { Percentage } \\
\text { adult } \\
\text { emergence }\end{array}$ & $\begin{array}{c}\text { Adult } \\
\text { weight at } \\
\text { emergence }\end{array}$ & $\begin{array}{c}\text { Mean } \\
\text { development } \\
\text { at time }\end{array}$ & $\begin{array}{c}\text { Number } \\
\text { of adults } \\
\text { emerged }\end{array}$ \\
\hline Control & $353 \pm 17 \mathrm{ab}$ & $97 \pm 0.6 \mathrm{a}$ & $91 \pm 3 \mathrm{a}$ & $3.8 \pm 0.2 \mathrm{a}$ & $31 \pm 2 \mathrm{a}$ & $316 \pm 8 \mathrm{ab}$ \\
\hline 2-tridecanone & $183 \pm 20 \mathrm{c}$ & $11 \pm 5 \mathrm{c}$ & $66 \pm 8 \mathrm{~b}$ & $3.8 \pm 0.1 \mathrm{a}$ & $34 \pm 0.5 \mathrm{a}$ & $13 \pm 5 \mathrm{c}$ \\
\hline 2-tridecanone 1:10 & $276 \pm 30 \mathrm{bc}$ & $49 \pm 7 \mathrm{~b}$ & $85 \pm 2 \mathrm{a}$ & $3.7 \pm 0.2 \mathrm{a}$ & $33 \pm 0.5 \mathrm{a}$ & $115 \pm 12 \mathrm{c}$ \\
\hline 2-tridecanone 1:100 & $274 \pm 20 \mathrm{bc}$ & $95 \pm 1 \mathrm{a}$ & $92 \pm 6 \mathrm{a}$ & $3.7 \pm 0.2 \mathrm{a}$ & $32 \pm 1 \mathrm{a}$ & $240 \pm 22 \mathrm{~b}$ \\
\hline 2-tridecanone 1:1000 & $430 \pm 20 \mathrm{a}$ & $97 \pm 0.2 \mathrm{a}$ & $91 \pm 0.5 \mathrm{a}$ & $3.8 \pm 0.1 \mathrm{a}$ & $33 \pm 2 \mathrm{a}$ & $339 \pm 15 \mathrm{a}$ \\
\hline
\end{tabular}

${ }^{a}$ Means within a column followed by the same letter are not significantly different at $P=0.05$ (Tukey's test).

text, the identification of naturally occurring substances with insecticidal activity to cowpea weevil is of special interest.

Furthermore, the potential use of essential oils in integrated pest management strategy to control insect damage was confirmed. However, further investigations are needed to understand their mechanism of action.

\section{ACKNOWLEDGMENTS}

This work was supported by grants from Conselho Nacional de Desenvolvimento Científico e Tecnológico (CNPq), Coordenação de Aperfeiçoamento de Pessoal de Nível Superior (CAPES), Fundação de Apoio à Ciência e Cultura (FUNCAP) e Banco do Nordeste do Brasil (BNB).

\section{RESUMO}

O efeito dos vapores da 2-tridecanona sobre o caruncho do feijão-de-corda (Callosobruchus maculatus) foi avaliado. Sementes de feijão-de-corda infestados com insetos adultos foram expostas a diferentes doses de 2-tridecanona isolada de Pilocarpus microphyllus, uma espécie nativa do Nordeste do Brasil. O monoterpeno puro foi utilizado nas diluições 1:10, 1:100 e 1:1000 (v/v). Os parâmetros da biologia do inseto foram analisados em função da resposta a doses decrescentes de 2tridecanona: número de ovos postos por fêmea, percentagem de eclosão de ovos, percentagem de emergência de adultos, peso dos adultos recém-emergidos, tempo médio de desenvolvimento e número total de ovos emergidos. Diferenças significativas $(\mathrm{P}<0.05)$ entre as doses de 2-tridecanona testadas foram observadas, para quatro dos seis parâmetros bi- ológicos analisados. Os resultados obtidos indicaram que a 2-tridecanona é tóxica para C. maculatus, reduzindo significativamente $(\mathrm{P}<0.05)$ o número de insetos emergidos após a infestação. Esse efeito foi causado principalmente pela significativa redução observada na eclosão dos ovos expostos ao vapor da substância.

Palavras-chave: Callosobruchus maculatus, feijão-de-corda, 2-tridecanona, Pilocarpus microphyllus.

\section{REFERENCES}

ADAMS RP. 2001. In Identification of Essential Oils Components by Gas Chromatography/Qruadrupole Mass Spectroscopy. Illinois: Allured.

Alencar JW, Craveiro AA, Matos FJA And MachaDO MIL. 1990. Kovat's indices simulation in essential oils analysis. Química Nova 13: 282-284.

Andrade-Neto M, Mafezoli J, Cunha UA, Silveira SC AND SILVEIRA ER. 1995. Volatile constituents of Pilocarpus trachyllophus Holmes. J Essent Oil Res 7: 671-674.

Andrade-Neto M, Cunha UA, Mafezoli J and SilVEIRA ER. 2002. Volatile Constituents of different populations of Pilocarpus spicatus Saint Hill. (Rutaceae) from the Northeast of Brazil. J Essent Oil Res 14: 319-324.

Craveiro AA, Matos FJA And Alencar JW. 1979. Essential oil from Brazilian Rutaceae. 1. Genus Pilocarpus. J Nat Prod 42: 669-671.

Craveiro AA, Matos FJA And Alencar JW. 1984. Kovat's indices as preselection routine in mass spectra library search of volatiles. J Nat Prod 47: 890-892.

Ehlers JD AND Halla AE. 1997. Cowpea (Vigna unguiculata L. Walp.). Field Crops Res 53: 187-204. 
Gilardon E, Pocovi M, Hernandez C, Collavino G AND Olsen A. 2001. Papel da 2-tridecanona e dos tricomas glandulares tipo VI na resistência do tomateiro a Tuta absoluta. Pes Agropec Bras 36: 929-933.

Hough-GoldsteIn JA. 1990. Antifeedant effects of common herbs on the Colorado potato beetle. Environ Entomol 19: 234-238.

KARR LL AND COATS JR. 1988. Insecticidal properties of $d$-limonene. J Pestic Sci 13: 287-290.

Keita SM, Vincent C, SChmit JP, Ramaswamy S And BÉLANGER A. 2000. Effect of various essential oils on Callosobruchus maculatus (F.) (Coleoptera: Bruchidae). J Stored Prod 36: 355-364.

Keita SM, Vincent C, Schmit JP, Annason JT And BÉLANGer A. 2001. Efficacy of essential oil from Ocimum basilicum $\mathrm{L}$. and Ocimum gratissimum L. applied as an insecticidal fumigant and powder to control Callosobruchus maculatus. J Stored Prod 37: 339-349.

KENNEDY GG, FARRAR RR AND KASHYAP RK. 1991. 2Tridecanone-glandular trichome-mediated insect resistance in tomato. Nat Occurring Pest Bioregul, p. 150-161.

Lin SYH, TRUmble JT AND Kumamoto J. 1987. Activity of volatile compounds in glandular trichomes of Lycopersicon species against two insect herbivores. J Chem Ecol 13: $837-850$.

Pascual-Villalobos MJ and Ballesta-Acosta MC. 2003. Chemical Variation in an Ocimun basilicum germplasm collection and activity of the essential oils on Callosobruchus maculatus. Biochem Syst Ecol 31: 673-679.

Raja N, Albert S, Ignacimuthu S and Dorn S. 2001. Effect of plant volatile oils in protecting stored cowpea Vigna unguiculata (L.) Walpers against Callosobruchus maculatus (F.) (Coleoptera: Bruchidae) infestation. J Stored Prod Res 37: 127-132.
RICE PJ AND COATS JR. 1994. Insecticidal properties of several monoterpenoids to the house fly, red flour beetle on southern maize rootwor'm. J Econ Entomol 87: 1172 1179.

ShaAya F, Kostuukovski M, Eiberg J and SukpraKARN C. 1997. Plant oils as fumigants and contact insecticides for the control of stored-product insects. J Stored Prod 33: 7-15.

Singh BB, Ajeigbe HA, Tarawali SA, FernandezRiverA S AND ABUBAKAR M. 2003. Improving the production and utilization of cowpea as food and fodder. Field Crops Res 84: 169-177.

Stenhagen E, Abrahamson S and McLafferty FW. 1974. In: Registry of Mass Spectral Data Base. J Wiley \& Sons, New York, USA.

Tsao R, Lee S, Rice PJ, Jensen C And CoAts JR. 1995. Monoterpenoids and their synthetic derivatives as leads for new insect control agents. Synthesis and Chemistry of Agrochemicals IV. ACS Sym Ser 584: 312-324.

Watanabe K, Shono Y, Kakimizu A, OKada A, Matsuo N, Satoh A ANd Nishimura H. 1993. New mosquito repellent from Eucalyptus camaldulensis. J Agr Food Chem 41: 2164-2166.

Williams WG, Kennedy GG, THACKeR JD AND BoRDNER J. 1980. 2-tridecanone: a naturally occurring insecticide from the wild tomato Lycopersicon hirsutum $\mathrm{f}$. glabratum. Science 62: 1427-1431. 